\title{
Analisis Pengaruh Rotasi Kerja, Motivasi Kerja dan Kepuasan Kerja terhadap Kinerja Karyawan di Lembaga Keuangan Mikro Syariah
}

\author{
Taufikur Rahman \\ Fakultas Ekonomi dan Bisnis Islam IAIN Salatiga \\ Email: takur067782@yahoo.co.id \\ Siti Solikhah \\ Fakultas Ekonomi dan Bisnis Islam IAIN Salatiga \\ Email: Sitisolikhah240@gmail.com
}

\begin{abstract}
This study aims at investigating and analyzing the effect of job rotation (X1), motivation (X2), and job satisfaction (X3) toward employees' performance (Y). The population used in this study is all employee of BMT Taruna Sejahtera that consists of 172 people. The writer took 120 employees as the sample of this research. The sampling technique used in this research is a probability sampling technique, which is sampling technique that provides an equal opportunity for all members of the population to be selected as the sample. The method used to collect the data is questionnaire. To analyze the data, the writer used a statistical test that includes t-test, F-test, the coefficient of determination (R2), and multiple regression tests. The process of data analysis is using a means of IBM SPSS Statistics 23.

Research finding shows that multiple linear regression equation $\mathrm{Y}$ is -12.335 $+0.364 \mathrm{X} 1+0.296 \mathrm{X} 2+0.235 \mathrm{X} 3+0: 05$. Results of t-test show that the variables of job rotation, motivation, and job satisfaction have positive and significant influence toward employees' performance. In other words, those variables jointly influence employees' performance. The coefficient of determination (R2) is 0.883 . It means that the contribution of independent variables (job rotation, motivation and job satisfaction) has influence toward dependent variable (employees' performance) amounted to $88.3 \%$, while the rest is $11.7 \%$ influenced by other variables out of research model.
\end{abstract}

Keywords: work rotation, motivation, job satisfaction, employees' performance 


\begin{abstract}
Abstrak
Tujuan penelitian ini adalah untuk mengetahui dan menganalisis pengaruh rotasi kerja (X1), motivasi kerja (X2) dan kepuasan kerja (X3) terhadap kinerja karyawan (Y). Populasi yang digunakan dalam penelitian ini adalah seluruh karyawan BMT Taruna Sejahtera dengan jumlah 172 karyawan. Sampel yang digunakan sebagai objek dalam penelitian ini sejumlah 120 karyawan. Teknik pengambilan sampel dalam penelitian ini adalah teknik probability sampling, yaitu teknik sampling yang memberikan peluang yang sama bagi seluruh anggota populasi untuk dipilih menjadi anggota sampel. Metode pengumpulan data dilakukan dengan angket/kuesioner. Teknik analisis yang digunakan adalah uji statistik melalui uji ttest, F-test, koefisien determinasi (R2), dan uji regresi berganda. Pengolahan data dalam penelitian ini menggunakan alat bantu IBM SPSS Statistics 23.

Berdasarkan hasil penelitian diperoleh persamaan regresi linear berganda $\mathrm{Y}$ $=-12,335+0.364 \mathrm{X} 1+0.296 \mathrm{X} 2+0.235 \mathrm{X} 3+0.05$. Hasil uji t-test menunjukkan bahwa variabel rotasi kerja mempunyai pengaruh positif dan signifikan terhadap kinerja karyawan, variabel motivasi kerja berpengaruh positif dan signifikan terhadap kinerja karyawan dan variabel kepuasan kerja berpengaruh positif dan signifikan terhadap kinerja karyawan. Hasil uji F-test menunjukkan bahwa rotasi kerja, motivasi kerja dan kepuasan kerja secara bersama-sama berpengaruh terhadap kinerja karyawan. Sedangkan hasil koefisien determinasi (R2) sebesar 0,883 ini berarti kontribusi variabel independen (rotasi kerja, motivasi kerja dan kepuasan kerja) mempengaruhi variabel dependen (kinerja karyawan) sebesar $88,3 \%$ sedangkan sisanya sebesar $11,7 \%$ dipengaruhi variabel lain di luar model penelitian.
\end{abstract}

Kata Kunci: rotasi kerja, motivasi kerja, kepuasan kerja, kinerja karyawan

\title{
Pendahuluan
}

Seiring berkembangnya perbankan syariah saat ini yang begitu pesat diikuti juga dengan perkembangan lembaga keuangan mikro syariah lain seperti Baitul Mal Wat Tamwil (BMT). BMT merupakan lembaga keuangan non bank yang mempunyai fungsi sebagai perantara investor dengan debitur sesuai dengan syari'at Islam. BMT saat ini merupakan lembaga keuangan mikro syariah yang begitu cepat perkembangannya. Hal tersebut ditandai dengan munculnya BMT-BMT baru di daerah-daerah baik yang ada di tengah kota maupun pinggir kota. Seiring dengan fenomena tersebut maka muncul 
pula permasalahan-permasalahan yang terjadi saat ini di lembaga keuangan syariah berbentuk BMT tersebut. Permasalahan tidak hanya dalam kegiatan operasionalnya yang berkaitan dengan produk-produk yang ditawarkan, kualitas layanan ataupun tingkat kesehatan, akan tetapi permasalahan Sumber Daya Manusia (SDM) juga menjadi permasalahan bagi lembaga keuangan syariah tersebut.

Menurut Mangkunegara (2008: 1) Sumber Daya Manusia di perusahaan perlu dikelola secara baik dan profesional agar terwujud keseimbangan antara kebutuhan pegawai dengan tuntutan dan kemampuan organisasi perusahaan. Keberhasilan kinerja suatu perusahaan salah satunya ditentukan oleh hasil kinerja karyawan yang baik, dan kinerja karyawan yang baik tercipta dengan melakukan pengelolaan Sumber Daya Manusia yang baik dan profesional. Rivai dan Sagala (2009: 604) mengemukakan bahwa kinerja merupakan hasil atau prestasi yang dipengaruhi oleh kegiatan operasional perusahaan dalam memanfaatkan sumber daya yang dimiliki. Kinerja karyawan di pengaruhi oleh beberapa faktor, salah satu faktor yang dapat mempengaruhi kinerja karyawan adalah rotasi kerja. Kaymaz (2010) mengungkapkan bahwa rotasi kerja dapat meningkatkan produktifitas kerja karena akan berpengaruh terhadap kinerja karyawan tersebut. Rotasi kerja menurut Robbins dan Judge (2008: 272) adalah pergantian periodik seorang karyawan dari satu tugas ke tugas lain. Ketika satu aktifitas tidak lagi menantang, karyawan tersebut dipindah ke pekerjaan lain, biasanya pada tingkat yang sama, yang mempunyai persyaratan-persyaratan keterampilan yang sama.

Penelitian tentang pengaruh rotasi kerja terhadap kinerja karyawan telah dilakukan oleh peneliti terdahulu yaitu Nurlatifah (2009), Putri (2013) dan Andriani (2013). Hasil penelitiannya menunjukkan bahwa rotasi kerja berpengaruh positif dan signifikan terhadap kinerja karyawan. Artinya ketika rotasi kerja meningkat maka kinerja karyawan juga akan mengalami peningkatan. Namun, penelitian yang dilakukan oleh Anggraini (2013) menunjukkan hasil yang berbeda. Hasil penelitiannya menunjukkan hasil yang negatif terhadap kinerja karyawan. Artinya ketika rotasi kerja meningkat, maka kinerja karyawan mengalami penurunan.

Faktor lain untuk mencapai kinerja karyawan yang baik selain rotasi kerja adalah dengan memperhatikan faktor kepuasan kerja seorang karyawan. 
Menurut Rivai dan Sagala (2009: 856) kepuasan kerja pada dasarnya sesutu yang bersifat individual. Setiap individu memiliki tingkat kepuasan yang berbeda-beda sesuai dengan sistem nilai yang berlaku pada dirinya. Makin tinggi penilaian terhadap kegiatan dirasakan sesuai dengan keinginan individu, maka makin tinggi kepuasannya terhadap kegiatan tersebut. Menurut Wahab (2012: 17) kepuasan kerja juga mempunyai arti penting untuk aktualisasi diri karyawan. Karyawan yang tidak mendapatkan kepuasan kerja tidak akan mencapai kematangan psikologis. Seseorang yang merasakan kepuasan diri dengan hasil kerjanya maka karyawan itu akan puas dengan hasil kerjanya walaupun hanya sedikit. Dengan meningkatnya kepuasan kerja, maka karyawan akan merasa lebih nyaman di perusahaan tersebut dan karyawan akan bekerja lebih baik dan dapat memperbaiki dirinya. Menurut Armstrong (1988: 105) kepuasan kerja adalah ukuran proses pembangunan iklim manusia yang berkelanjutan dalam suatu organisasi. Kepuasan kerja yang tinggi dapat dikaitkan dengan hasil positif yang mereka harapkan. Dengan kata lain berati kepuasan kerja berpengaruh positif dengan kinerja karyawan.

Penelitian tentang pengaruh kepuasan kerja terhadap kinerja karyawan pernah dilakukan oleh Syahbandar (2011) dan Wahab (2012). Hasil penelitian tersebut menunjukkan bahwa kepuasan kerja berpengaruh positif dan signifikan terhadap kinerja karyawan. Artinya ketika kepuasan kerja meningkat maka kinerja karyawan juga akan mengalami peningkatan. Sedangkan penelitian yang dilakukan oleh Gumilar (2010) menunjukkan hasil yang berbeda yaitu kepuasan kerja berpengaruh negatif terhadap kinerja karyawan. Artinya ketika kepuasan kerja meningkat, maka kinerja karyawan mengalami penurunan.

Selain kepuasan kerja, perusahaan juga harus memperhatikan, menjaga dan mengelola motivasi pegawai. Seperti yang dikemukakan oleh Armstrong (1988: 66) bahwa motivasi adalah memastikan bahwa orang bergerak ke arah yang diinginkan. Memberikan motivasi pada karyawan dapat memberikan dukungan kepada karyawan agar karyawan tetap bekerja lebih baik dan dapat meningkatkan kinerja karyawan, sehingga dapat dikatakan variabel motivasi kerja berpengaruh positif terhadap kinerja karyawan. Menurut Mangkunegara (2004:68) motivasi terbentuk dari sikap (attitude) seorang karyawan dalam menghadapi situasi. Motivasi merupakan kondisi 
dimana dapat menggerakkan diri karyawan yang terarah untuk mencapai tujuan perusahaan. Motivasi yang timbul dari seorang karyawan diharapkan mampu meningkatkan kinerja karyawan.

Penelitian tentang pengaruh motivasi kerja terhadap kinerja karyawan telah dilakukan oleh Rahmawati (2010) dan Nitasari (2012). Hasil penelitiannya menunjukkan bahwa motivasi kerja berpengaruh positif dan signifikan terhadap kinerja karyawan. Artinya ketika motivasi kerja meningkat maka kinerja karyawan juga akan mengalami peningkatan. Sedangkan penelitian yang dilakukan oleh Murti dan Veronika (2013) menunjukkan hasil yang berbeda yakni motivasi berpengaruh negatif terhadap kinerja karyawan. Artinya ketika motivasi kerja meningkat, maka kinerja karyawan mengalami penurunan.

Perbedaan penelitian ini dengan penelitian-penelitian terdahulu adalah penelitian ini lebih berfokus untuk mengetahui pengaruh ketiga faktor yaitu rotasi kerja, motivasi kerja dan kepuasan kerja terhadap kinerja karyawan di Lembaga Keuangan Mikro Syariah.

\section{Landasan Teori}

\section{Rotasi Kerja}

Menurut Robbins dan Judge (2008: 272) rotasi kerja adalah pergantian periodik seorang karyawan dari satu tugas ke tugas lain. Ketika satu aktifitas tidak lagi menantang, karyawan tersebut dipindah ke pekerjaan lain, biasanya pada tingkat yang sama, yang mempunyai persyaratan-persyaratan keterampilan yang sama. Rotasi pekerjaan secara tidak langsung memberikan manfaat bagi organisasi karena karyawan yang mempunyai banyak keterampilan memberi manajemen lebih banyak dalam merencanakan pekerjaan, menyesuaikan diri terhadap perubahan dan mengisi lowonganlowongan. Rotasi kerja menurut Nurlatifah (2009: 3) selain berfungsi bagi pengembangan sumber daya manusia rotasi kerja diyakini dapat memberikan banyak manfaat lain bagi organisasi, rotasi dapat mencegah timbulnya kebosanan dan dapat juga mengurangi labour turnover (absennya pekerja) karyawan. Manfaat tidak langsung, rotasi kerja bagi organisasi adalah ketika karyawan yang memiliki katrampilan lebih luas pada berbagai bidang 
pekerjaan, sehingga lebih mudah dalam penjadwalan kerja, mengatur cuti karyawan dan beradaptasi terhadap perubahan. Adapun indikator rotasi pekerjaan yang dikembangkan oleh Kaymaz (2010: 74) yaitu: tingkat kejenuhan kerja; tambahan pengetahuan, keterampilan, dan kompetensi; persiapan manajemen; pilihan posisi kerja yang tepat; pengembangan hubungan sosial.

\section{Motivasi Kerja}

Menurut Rivai dan Sagala (2009: 837) motivasi adalah serangkaian sikap dan nilai-nilai yang mempengaruhi individu untuk mencapai hal yang spesifik sesuai dengan tujuan individu. Sikap dan nilai tersebut merupakan suatu yang invisible yang memberikan kekuatan untuk mendorong individu bertingkah laku dalam mencapai tujuan. Menurut Wahjono (2010: 78) motivasi adalah adalah serangkaian upaya untuk mempengaruhi tingkah laku orang lain dengan mengetahui terlebih dahulu tentang apa yang membuat seseorang bergerak. Namun seseorang bergerak itu bergerak karena dua sebab yaitu kemampuan (ability) dan motivasi. Jadi dapat disimpulkan bahwa motivasi adalah serangkaian sikap dan nilai-nilai yang mempengaruhi individu yang dapat menimbulkan dorongan atau semangat kerja untuk mencapai tujuan.

Menurut Rivai dan Sagala (2009: 840) teori motivasi antara lain: Hierarki Teori Kebutuhan (Hierarchial of Needs Theory). Teori yang terkenal adalah teori kebutuhan yang dikemukakan oleh Abraham Maslow. Kemudian David McCelland menganalisis tentang tiga kebutuhan manusia yang sangat penting di dalam organisasi atau perusahaan tentang motivasi, tiga hal tersebut antara lain: need for achievement (kebutuhan dalam mencapai kesuksesan), need for powwer, need for affiliation (kebutuhan untuk berafiliasi).

Faktor-faktor motivasi kerja menurut Gomes (2003: 180) antara lain: faktor -faktor yang sifatnya individual dan faktor-faktor yang berasal dari organisasi. Sedangkan menurut Wahab (2012: 36), faktor-faktor yang mempengaruhi motivasi antara lain: upah, situasi kerja, kondisi kerja yang akan mendorong semangat kerja karyawan seperti ketenangan, keamanan, dan keselamatan kerja, fasilitas kerja, sikap manajemen terhadap karyawan, setiap karyawan pada dasarnya ingin diperlakukan dengan adil. 


\section{Kepuasan Kerja}

Kepuasan kerja merupakan bentuk perasaan seseorang terhadap pekerjaannya, situasi kerja dan hubungan dengan rekan kerja. Dengan demikian kepuasan kerja merupakan sesuatu yang penting untuk dimiliki oleh seorang karyawan, dimana mereka dapat melaksanakan dengan baik dan sesuai dengan tujuan perusahaan (Wahab, 2012: 24). Menurut Rivai dan Sagala (2009: 856) kepuasan kerja pada dasarnya sesutu yang bersifat individual. Setiap individu memiliki tingkat kepuasan yang berbeda-beda sesuai dengan sistem nilai yang berlaku pada dirinya. Makin tinggi penilaian terhadap kegiatan dirasakan sesuai dengan keinginan individu, maka makin tinggi kepuasannya terhadap kegiatan tersebut. Jadi dapat disimpulkan bahwa kepuasan kerja adalah keadaan emosional seseorang terhadap pekerjaannya, dan sikap yang timbul berdasarkan penilaian terhadap situasi kerja.

Menurut Spector dalam Gumilar (2010: 28) mengidentifikasi terdapat sembilan faktor yang mempengaruhi kepuasan kerja dengan nama Job Satisfaction Survey (JSS), yaitu: gaji/ upah, promosi, supervisi, tunjangan-tunjangan, penghargaan, peraturan/ prosedur, rekan kerja, pekerjaan itu sendiri, komunikasi. Menurut Mangkunegara (2008: 120) ada dua faktor yang mempengaruhi kepuasan kerja, yaitu: faktor pegawai dan faktor pekerjaan. Menurut Rivai dan Sagala (2009: 856) teori tentang kepusaan kerja yang cukup dikenal antara lain, yaitu: Teori Ketidakpuasan (Discrepancy theory), teori Keadilan (Equity theory) dan teori dua faktor (Two factor theory). Menurut Rivai dan Sagala (2009: 860) faktor-faktor yang mempengaruhi kepuasan kerja yang biasanya digunakan untuk mengukur kepuasan kerja seorang karyawan adalah: (a) isi pekerjaan, penampilan tugas pekerjaan yang aktual dan sebagai kontrol terhadap pekerjaan; (b) supervisi; (c) organisasi dan manajemen; (d) kesempatan untuk maju; (e) gaji dan keuntungan dalam bidang finansial lainnya seperti adanya insentif; (f) rekan kerja; (g) kondisi pekerjaan.

\section{Kinerja Karyawan}

Menurut Rivai dan Sagala (2009: 548) kinerja merupakan suatu fungsi dari motivasi dan kemampuan. Untuk menyelesaikan tugas atau pekerjaan seseorang sepatutnya memiliki derajat kesediaan dan tingkat kemampuan 
tertentu. Kesediaan dan keterampilan seseorang tidaklah cukup efektif untuk mengerjakan sesuatu tanpa pemahaman yang jelas tentang apa yang akan dikerjakan dan bagaimana mengerjaknnya. Kinerja merupakan perilaku nyata yang ditampilkan setiap orang sebagai prestasi kerja yang dihasilkan oleh karyawan sesuai dengan perannya dalam perusahaan. Kinerja karyawan merupakan suatu hal yang sangat penting dalam upaya perusahaan untuk mencapai tujuannya. Jadi dapat disimpulkan bahwa kinerja karyawan adalah hasil kerja kualitas dan kuantitas yang dicapai seseorang dan tentang apa yang dikerjakan dan bagaimana cara mengerjakannya sehingga dapat mempengaruhi produktivitas dan kinerja organisasional secara signifikan.

Faktor yang mempengaruhi pencapaian kinerja adalah faktor kemampuan (ability) dan faktor motivasi (motivation). Hal ini sesuai dengan pendapat Keith Davis dalam Mangkunegara (2008: 67-68) yang merumuskan bahwa: Human Performance = Ability + Motivation, Motivation $=$ Attitude + Situation, Ability $=$ Knowledge + Skill. Menurut Wibowo (2010: 102) indikator kinerja antara lain: 1) Tujuan, tujuan merupakan sesuatu keadaan yang lebih baik yang ingin dicapai di masa yang akan datang, 2) Standar, standar merupakan suatu ukuran apakah tujuan yang diinginkan dapat dicapai, 3) umpan balik, umpan balik merupakan masukan yang dipergunakan untuk mengukur kemajuan kinerja, standar kinerja, dan pencapaian tujuan, 4) alat atau sarana, alat atau sarana merupakan sumber daya yang dapat dipergunakan untuk membantu menyelesaikan tujuan dengan sukses 5) motif, motif merupakan alasan atau pendorong bagi seseorang untuk melakukan sesuatu, 6) peluang, pekerja perlu mendapatkan kesempatan untuk menunjukkan prestasi kerjanya.

\section{Pengaruh Rotasi Kerja Terhadap Kinerja Karyawan}

Rotasi kerja dari apa yang telah disampaikan Kaymaz (2010) dalam penelitiannya mengungkapkan bahwa model yang berkaitan dengan desain pekerjaan dapat diklasifikasikan sebagai rotasi pekerjaan, perluasan kerja dan sebagainya. Rotasi pekerjaan diperkirakan dapat memberikan kepuasan kerja dan meningkatkan produktifitas kerja yang tertinggi ketika penambahan dan pengkayaan pekerjaan secara bersama-sama dapat diterapkan untuk mendesain suatu sistem kerja yang sesuai. Karena sebagian besar 
menganggap rotasi pekerjaan mampu diterima sebagai metode yang efektif untuk mengembangkan keterampilan dan meningkatkan kepuasan kerja yang akhirnya berpengaruh terhadap kinerja.

Menurut Santoso dan Riyardi (2012:27) dengan rotasi kerja, para karyawan dapat memulai dengan tugas dan fungsi dan tempat pekerjaan yang baru. Di sinilah para karyawan mulai belajar, baik dalam tugas dan fungsi yang baru di dalam pekerjaannya, maupun siap dalam menghadapi berbagai persoalan dan kesulitan dalam pekerjaannya, yang berbeda dengan tugas di tempat pekerjaan sebelumnya. Dari uraian di atas, maka hipotesis yang diajukan adalah sebagai berikut:

H1 : Rotasi kerja berpengaruh positif dan signifikan terhadap kinerja karyawan.

\section{Pengaruh motivasi kerja terhadap kinerja karyawan}

Armstrong (1988:65) mengemukakan bahwa "memotivasi sumber daya manusia dapat mendorong prestasi kerja yang tinggi dan dapat mendorong karyawan untuk berusaha sebaik-baiknya kepentingan perusahaan dan kepentingan karyawan itu sendiri". Hal ini karyawan dapat bekerja secara lebih giat dan lebih baik sehingga dapat meningkatkan prestasi kerjanya sehingga dapat meningkatkan kinerjanya. Teori yang terkenal adalah teori kebutuhan yang dikemukakan oleh Abraham Maslow (Rivai dan Sagala, 2009: 840), menurut Maslow pada setiap diri manusia itu terdiri dari atas lima kebutuhan yaitu: kebutuhan secara fisiologis, rasa aman, sosial, penghargaan dan aktualisasi diri.

Penelitian tentang pengaruh motivasi kerja terhadap kinerja karyawan yang telah dilakukan adalah penelitian Wahab (2012) yang hasil penelitiannya menunjukkan bahwa motivasi kerja berpengaruh positif dan signifikan terhadap kinerja karyawan. Namun, penelitian yang dilakukan Murti dan Srimulyani (2013) menunjukkan hasil yang berbeda yaitu motivasi kerja tidak berpengaruh terhadap kinerja karyawan. Menurut Wibowo (2010: 389) karyawan akan termotivasi ketika kinerja mereka akan dikenal dan dihargai. Perilaku termotivasi secara langsung dipengaruhi oleh kemampuan dan pengetahuan/keterampilan kerja individu, motivasi dan kombinasi yang me- 
mungkinkan dan membatasi faktor konteks pekerjaan. Dari uraian di atas, maka hipotesis yang diajukan adalah sebagai berikut:

H2 : Motivasi kerja berpengaruh positif terhadap kinerja karyawan.

\section{Pengaruh kepuasan kerja terhadap kinerja karyawan}

Kepuasan kerja merupakan bentuk perasaan seseorang terhadap pekerjaannya, situasi kerja dan hubungan dengan rekan kerja. Dengan demikian kepuasan kerja merupakan sesuatu yang penting untuk dimiliki oleh seorang karyawan, dimana mereka dapat dilaksanakan dengan baik dan sesuai dengan tujuan perusahaan (Wahab, 2012: 24). Teori kepuasan kerja yaitu teori dua Faktor dari Herzberg, dua faktor yang dapat menyebabkan timbulnya rasa puas atau tidak puas menurut Herzberg, yaitu faktor pemeliharaan (maintenance factors) dan faktor pemotivasian (mitivational factors). Faktor pemeliharaan meliputi administrasi dan kebijakan perusahaan, kualitas pengawasan, hubungan dengan pengawas, hubungan dengan subordinate, upah, keamanan kerja, kondisi kerja dan status. Sedangkan faktor pemotivasian meliputi dorongan berprestasi, pengenalan, kemajuan (advancement), work it self, kesempatan berkembang dan tanggung jawab (Rivai dan Sagala, 2009: 856).

Penelitian pengaruh kepuasan kerja terhadap kinerja karyawan telah dilakukan yaitu Syahbandar (2011) yang hasil penelitiannya menunjukkan bahwa kepuasan kerja berpengaruh positif dan signifikan terhadap kinerja karyawan. Akan tetapi, penelitian yang dilakukan Gumilar (2010) menunjukkan hasil yang berbeda yaitu kepuasan kerja tidak berpengaruh yang signifikan terhadap kinerja karyawan. Menurut Martoyo (1987:132) kepuasan kerja terjadi tercermin pada perasaan karyawan terhadap pekerjaannya, yang sering diwujudkan dalam sikap positif karyawan terhadap pekerjaannya dan segala sesuatu yang dihadapi ataupun ditugaskan kepadanya di lingkungan kerjanya. Dari uraian di atas, maka hipotesis yang diajukan adalah sebagai berikut:

H3 : Kepuasan kerja berpengaruh positif terhadap kinerja karyawan. 


\section{Metode penelitian}

\section{Jenis penelitian}

Jenis penelitian yang digunakan dalam penelitian ini adalah penelitian kuantitatif. Penelitian kuantitatif adalah penelitian yang dilakukan dengan mengumpulkan data yang berupa angka. Data yang berupa angka tersebut kemudian diolah dan dianalisis untuk mendapatkan suatu informasi ilmiah di balik angka-angka tersebut (Martono, 2011: 20).

\section{Lokasi dan waktu penelitian}

Lokasi penelitian adalah BMT Taruna Sejahtera Ungaran dan cabangnya. Waktu penelitian dilaksanakan pada bulan November tahun 2015.

\section{Populasi dan sampel}

Populasi adalah seluruh kumpulan (orang, kejadian, produk) yang dapat digunakan untuk membuat beberapa kesimpulan, populasi bisa disebut sebagai totalitas subjek penelitian (Wijaya 2013: 27). Dalam penelitian ini populasinya adalah karyawan di BMT Taruna Sejahtera Ungaran, jumlah populasi 172 karyawan.

Sugiyono dalam Martono (2011: 75) sampel adalah bagian dari suatu subjek atau objek yang mewakili populasi. Pengambilan sampel dalam penelitian ini menggunakan teknik probability sampling, yaitu teknik sampling yang memberikan peluang yang sama bagi seluruh anggota populasi untuk dipilih menjadi anggota sampel. Berdasarkan populasi dengan tingkat kesalahan yang peneliti gunakan adalah 5\%. Rumus yang digunakan untuk menentukan jumlah sampel adalah rumus Slovin dalam Bawono (2006), sebagai berikut:

$$
\begin{aligned}
\mathrm{N}: 172, \mathrm{e}: 5 \%, \mathrm{n}= & \frac{\mathrm{N}}{1+\mathrm{Ne}^{2}} \\
& \frac{172}{1+\left(172.0,05^{2}\right)} \\
& =120
\end{aligned}
$$




\section{Teknik pengumpulan data}

Dalam penelitian ini peneliti dalam teknik pengambilan data menggunakan data sumber primer, sumber primer adalah pengambilan data yang diperoleh secara langsung oleh peneliti dari lapangan (Bawono, 2006:29), sumber ini dapat diperoleh dengan cara: kuesioner (angket), wawancara dan studi kepustakaan. Penelitian ini memperoleh data dan informasi juga dari buku-buku, hasil penelitian sebelumnya seperti skripsi, tesis, jurnal dan bahan bacaan yang lain.

\section{Definisi konsep dan operasional}

Menurut Robbins dan Judge (2008: 272) rotasi kerja adalah pergantian periodik seorang karyawan dari satu tugas ke tugas lain. Ketika satu aktifitas tidak lagi menantang, karyawan tersebut dipindah ke pekerjaan lain, biasanya pada tingkat yang sama, yang mempunyai persyaratanpersyaratan keterampilan yang sama. Menurut Rivai dan Sagala (2009: 837) motivasi adalah serangkaian sikap dan nilai-nilai yang mempengaruhi individu untuk mencapai hal yang spesifik sesuai dengan tujuan individu. Kepuasan kerja adalah seperangkat perasaan pegawai tentang menyenangkan atau tidaknya pekerjaan mereka, kepuasan kerja merupakan perasaan senang atau tidak senang yang relatif yang berbeda dari pemikiran objektif dan keinginan perilaku (Davis dan Newstrom,1985:105). Menurut Mangkunegara (2008: 67) kinerja (prestasi kerja) adalah hasil kerja secara kualitas dan kuantitas yang dicapai oleh seorang pegawai dalam melaksanakan tugasnya sesuai dengan tanggung jawab yang diberikan kepadanya.

\section{Hasil dan Pembahasan}

\section{Profil Responden Berdasarkan Jenis Kelamin}

Berdasarkan data yang diperoleh menunjukkan bahwa responden terdiri dari 35\% laki-laki yaitu sebanyak 42 responden, dan $65 \%$ perempuan yaitu sebanyak 78 responden. 


\section{Profil Responden Berdasarkan Usia}

Berdasarkan data yang diperoleh menunjukkan bahwa responden yang berumur di bawah 20 tahun sebanyak 1,7\% yaitu sebanyak 2 responden, usia 20 sampai 30 tahun sebanyak $61,6 \%$ yaitu 74 responden, umur 31-40 tahun $34,2 \%$ yaitu 41 responden sedangkan terdapat responden yang tidak mengisi kolom umur yaitu 3 responden atau 2,5\%.

\section{Profil Responden Berdasarkan Lama Bekerja}

Berdasarkan data yang diperoleh menunjukkan bahwa $86,7 \%$ atau sebanyak 104 responden waktu lama bekerja kurang dari 5 tahun, sedangkan sebanyak $13,3 \%$ atau 16 karyawan tidak mencantumkan lama bekerja.

\section{Profil Responden Berdasarkan Penghasilan}

Berdasarkan data yang diperoleh menunjukkan $31,7 \%$ atau sebanyak 38 responden berpenghasilan Rp 1.000.100,00-Rp 2.000.000,00, sebanyak $51,6 \%$ atau 62 responden berpenghasilan Rp 2.000.100,00-Rp 3.000.000,00, sedangkan sisanya yaitu $16,7 \%$ atau 20 responden berpenghasilan lebih dari Rp 3.000.000,00. Hal ini menunjukkan bahwa 50\% dari responden BMT Taruna Sejahtera berpenghasilan Rp 2.000.100,00-Rp 3.000.000,00.

\section{Analisis data}

\section{Uji Validitas}

Validitas menunjukkan ketepatan dan kecermatan alat ukur dalam melakukan fungsi ukurannya. Suatu skala pengukuran disebut valid bila ia melakukan apa yang seharusnya dilakukan dan mengukur apa yang seharusnya diukur (Wijaya 2013: 88). Adapun kriteria penilaian uji validitas menurut Bawono (2006:69) dengan taraf signifikan $(\alpha)=0,05$, jika $r_{\text {hitung }}>r_{\text {tabel }}$, maka kuesioner sebagai alat pengukur dikatakan valid atau ada korelasi yang nyata antara kedua variabel tersebut. Untuk mencari $t{ }_{\text {tabel }}$ untuk degree of freedom $(\mathrm{df})=(\mathrm{n}-\mathrm{k}-1)=120-3-1=116$, dengan nilai $\mathrm{df}=116$ dan nilai alpha $=0.05$ atau $5 \%$ didapat angka $r_{\text {tabel }} 0.1809$. Untuk menguji apakah masing-masing indikator valid atau tidak, bisa di lihat tampilan tabel di bawah 
ini, jika $r$ hitung lebih besar dari $r$ tabel maka butir pertanyaan tersebut dinyatakan valid.

Tabel 1

Hasil Uji Validitas

\begin{tabular}{|c|c|c|c|c|}
\hline Variabel & Item Pertanyaan & $\mathbf{r}_{\text {hitung }}$ & $\mathbf{r}_{\text {tabel }}$ & Keterangan \\
\hline \multirow[t]{10}{*}{ Rotasi Kerja } & Rotasi Kerja 1 & 0.843 & \multirow{10}{*}{0.1809} & Valid \\
\hline & Rotasi Kerja 2 & 0.886 & & Valid \\
\hline & Rotasi Kerja 3 & 0.872 & & Valid \\
\hline & Rotasi Kerja 4 & 0.842 & & Valid \\
\hline & Rotasi Kerja 5 & 0.899 & & Valid \\
\hline & Rotasi Kerja 6 & 0.885 & & Valid \\
\hline & Rotasi Kerja 7 & 0.897 & & Valid \\
\hline & Rotasi Kerja 8 & 0.850 & & Valid \\
\hline & Rotasi Kerja 9 & 0.910 & & Valid \\
\hline & Rotasi Kerja 10 & 0.940 & & Valid \\
\hline \multirow[t]{11}{*}{ Motivasi Kerja } & Motivasi Kerja 1 & 0.770 & \multirow{11}{*}{0.1809} & Valid \\
\hline & Motivasi Kerja 2 & 0.823 & & Valid \\
\hline & Motivasi Kerja 3 & 0.950 & & Valid \\
\hline & Motivasi Kerja 4 & 0.947 & & Valid \\
\hline & Motivasi Kerja 5 & 0.952 & & Valid \\
\hline & Motivasi Kerja 6 & 0.949 & & Valid \\
\hline & Motivasi Kerja 7 & 0.969 & & Valid \\
\hline & Motivasi Kerja 8 & 0.956 & & Valid \\
\hline & Motivasi Kerja 9 & 0.937 & & Valid \\
\hline & Motivasi Kerja 10 & 0.941 & & Valid \\
\hline & Motivasi Kerja 11 & 0.955 & & Valid \\
\hline \multirow{11}{*}{$\begin{array}{l}\text { Kepuasan } \\
\text { Kerja }\end{array}$} & Kepuasan Kerja 1 & 0.934 & \multirow{11}{*}{0.1809} & Valid \\
\hline & Kepuasan Kerja 2 & 0.890 & & Valid \\
\hline & Kepuasan Kerja 3 & 0.957 & & Valid \\
\hline & Kepuasan Kerja 4 & 0.950 & & Valid \\
\hline & Kepuasan Kerja 5 & 0.944 & & Valid \\
\hline & Kepuasan Kerja 6 & 0.960 & & Valid \\
\hline & Kepuasan Kerja 7 & 0.952 & & Valid \\
\hline & Kepuasan Kerja 8 & 0.952 & & Valid \\
\hline & Kepuasan Kerja 9 & 0.961 & & Valid \\
\hline & Kepuasan Kerja10 & 0.966 & & Valid \\
\hline & Kepuasan Kerja 11 & 0.941 & & Valid \\
\hline \multirow[t]{8}{*}{ Kinerja } & Kinerja 1 & 0.949 & \multirow{8}{*}{0.1809} & Valid \\
\hline & Kinerja 2 & 0.966 & & Valid \\
\hline & Kinerja 3 & 0.960 & & Valid \\
\hline & Kinerja 4 & 0.959 & & Valid \\
\hline & Kinerja 5 & 0.987 & & Valid \\
\hline & Kinerja 6 & 0.949 & & Valid \\
\hline & Kinerja 7 & 0.957 & & Valid \\
\hline & Kinerja 8 & 0.937 & & Valid \\
\hline
\end{tabular}

Sumber: Data primer yang diolah 2015 
Berdasarkan Tabel 4.7 menunjukkan bahwa semua indikator yang digunakan untuk mengukur variabel rotasi kerja, motivasi kerja, kepuasan dan kinerja karyawan yang digunakan dalam penelitian ini mempunyai koefisien korelasi yang lebih besar dari 0.1809. Hal ini berarti bahwa semua indikator dan pertanyaan pada setiap variabel dalam penelitian ini adalah valid sehingga layak digunakan sebagai pengumpul data, dapat dianalisis selanjutnya.

\section{Uji Reliabilitas}

Menurut Hadi dalam Indrayati (2014:54) reliabilitas adalah derajat ketepatan atau akurasi yang ditunjukkan oleh instrumen penelitian. Menurut Nunnally dalam Bawono (2006:68) suatu variabel dikatakan reliabel jika nilai Cronbach Alpha > 0,60. Sehingga data tersebut bisa dikatakan reliabel untuk pengukuran dan meneliti selanjutnya.

Tabel 2

Hasil Uji Reliabilitas

\begin{tabular}{lcc}
\hline Variabel & Nilai Cronbach Alpha & Keterangan \\
\hline Rotasi Kerja (X1) & 0.975 & Reliable \\
Motivasi Kerja (X2) & 0.985 & Reliable \\
Kepuasan Kerja (X3) & 0.990 & Reliable \\
Kinerja Karyawan (Y) & 0.990 & Reliable \\
\hline
\end{tabular}

Sumber: Data primer yang diolah 2015

Hasil pengujian reliabilitas konstruk variabel yang digunakan dalam penelitian ini diperoleh nilai Cronbach Alpha yang lebih besar dari 0,60. Hal ini berarti bahwa seluruh instrumen dalam penelitian ini reliable, sehingga semua butir pertanyaan dapat dipercaya dan dapat digunakan untuk penelitian selanjutnya.

\section{Uji Asumsi Klasik}

\section{Uji Multicollinearity}

Multicollinearity adalah situasi di mana terdapat korelasi variabelvariabel bebas di antara satu dengan lainnya (Bawono, 2006:116). Dalam 
penelitian ini peneliti menggunakan cara auxilary regresi, yaitu membandingkan antara $\mathrm{r}^{2}$ (koefisien determinasi parsial) dan $\mathrm{R}^{2}$ (koefisien determinasi majemuk) untuk mengetahui ada atau tidaknya penyakit multikolinearitas, dibawah ini adalah hasil uji $\mathrm{R}^{2}$ regresi utama adalah sebagai berikut:

Tabel 3

Hasil $\mathrm{R}^{2}$ (koefisien determinasi majemuk) regresi utama

Model Summary

\begin{tabular}{|l|l|r|r|r|}
\hline Model & R & R Square & Adjusted R Square & Std. Error of the Estimate \\
\hline 1 &, $940^{\mathrm{a}}$ &, 883 &, 880 & 3,62673 \\
\hline
\end{tabular}

a. Predictors: (Constant), Jumlah_X3, Jumlah_X1, Jumlah_X2

Sumber: Data primer yang diolah 2015

Di bawah ini adalah hasil $\mathrm{r}^{2}$ (koefisien determinasi parsial) untuk setiap variabel independen yang diregresikan, setelah mendapatkan $r^{2}$ untuk setiap variabel independen, maka nilai dari $\mathrm{r}^{2}$ dibandingkan dengan nilai $\mathrm{R}^{2}$ untuk mengetahui ada atau tidaknya penyakit multikolinearitas yang diperoleh dalam penelitian ini adalah sebagai berikut:

Tabel 4

Perbandingan $\mathrm{r}^{2}$ dan $\mathrm{R}^{2}$

\begin{tabular}{lc}
\hline Regresi Antar Variabel Independen & $\mathrm{r}^{2}$ \\
\hline $\mathrm{X} 1=\mathrm{f}(\mathrm{X} 2, \mathrm{X} 3)$ & 0.763 \\
$\mathrm{X} 2=\mathrm{f}(\mathrm{X} 1, \mathrm{X} 3)$ & 0.870 \\
$\mathrm{X} 3=\mathrm{f}(\mathrm{X} 1, \mathrm{X} 2)$ & 0.853 \\
\hline \multicolumn{2}{c}{$\boldsymbol{R}^{2}=\mathbf{0 . 8 8 0}$} \\
\hline
\end{tabular}

Sumber: Data primer yang diolah 2015

Dari tabel di atas, menunjukkan bahwa $\mathrm{R}^{2}$ (koefisien determinasi majemuk sebesar 0.880 hasil regresi utama lebih besar dari $\mathrm{r}^{2}$ (koefisien determinasi parsial) yaitu sebesar $0.763,0.870,0.853$, sehingga dapat disimpulkan bahwa tidak ada gejala multikolinearitas.

\section{Uji Heteroscedasticity}

Uji heteroscedasticity bertujuan menguji apakah dalam model regresi terjadi ketidaksamaan variance dari residual satu pengamatan ke pengamatan 
yang lain. Jika variance dari residual satu pengamatan ke pengamatan yang lain tetap, maka disebut Homoskedastisitas dan jika berbeda disebut Heteroskedastisitas. Model regresi yang baik adalah yang Homoskedastisitas (Ghozali, 2001:69).

Dalam penelitian ini, peneliti menggunakan metode Glejser yaitu meregres nilai absolut residual terhadap variabel bebas (Gujarati dalam Ghozali, 2001:72). Pengambilan keputusannya adalah jika nilai signifikansi lebih dari nilai alfa (0.05) maka data tidak mengandung heteroskedastisistas, jika nilai signifikansi kurang dari 0,05 maka terdapat gejala heteroskedastisistas. Adapaun hasil uji heteroscedasticity sebagai berikut:

Tabel 5

Hasil Uji Heteroscedasticity

Coefficients $^{\mathrm{a}}$

\begin{tabular}{|c|c|c|c|c|c|c|}
\hline \multirow{2}{*}{\multicolumn{2}{|c|}{ Model }} & \multicolumn{2}{|c|}{$\begin{array}{l}\text { Unstandardized } \\
\text { Coefficients }\end{array}$} & \multirow{2}{*}{$\begin{array}{l}\text { Standardized } \\
\text { Coefficients } \\
\text { Beta }\end{array}$} & \multirow[b]{2}{*}{$\mathrm{T}$} & \multirow[b]{2}{*}{ Sig. } \\
\hline & & B & Std. Error & & & \\
\hline \multirow[t]{4}{*}{1} & (Constant) & 6,963 & 2,575 & & 2,704 &, 008 \\
\hline & Jumlah_x1 &,- 032 & 059 &,- 101 &,- 542 &, 589 \\
\hline & Jumlah_X2 & ,019 &, 052 & ,092 & ,366 &, 715 \\
\hline & Jumlah_X3 &,- 041 &, 047 &,- 207 &,- 875 & ,383 \\
\hline
\end{tabular}

a. Dependent Variable: Abs_Ut

Sumber: Data primer yang diolah 2015

Dari tabel di atas diketahui nilai signifikansi rotasi kerja (X1) 0,589, berarti data termasuk homogen karena diatas nilai 0,05. Nilai signifikasni untuk variabel motivasi kerja (X2) sebesar 0,715, ini berarti data termasuk homogen karena diatas nilai 0,05. Nilai signifikansi untuk variabel kepuasan kerja (X3) sebesar 0,383, ini berarti data termasuk homogen karena diatas nilai 0,05 . Jadi dapat disimpulkan bahwa model regresi tidak mengandung adanya heteroskedastisitas, sehingga asumsi persamaan regresi baik.

\section{Uji Normalitas}

Menurut Ghozali (2001:74) uji normalitas bertujuan untuk menguji apakah dalam model regresi variabel terikat dan variabel bebas keduanya mempunyai distribusi normal atau tidak. Model regresi yang baik adalah 
memiliki distribusi data normal atau mendekati normal. Adapun uji normalitas dalam penelitian menggunakan grafik normal plot. Grafik normal plot dapat terlihat dari gambar di bawah ini:

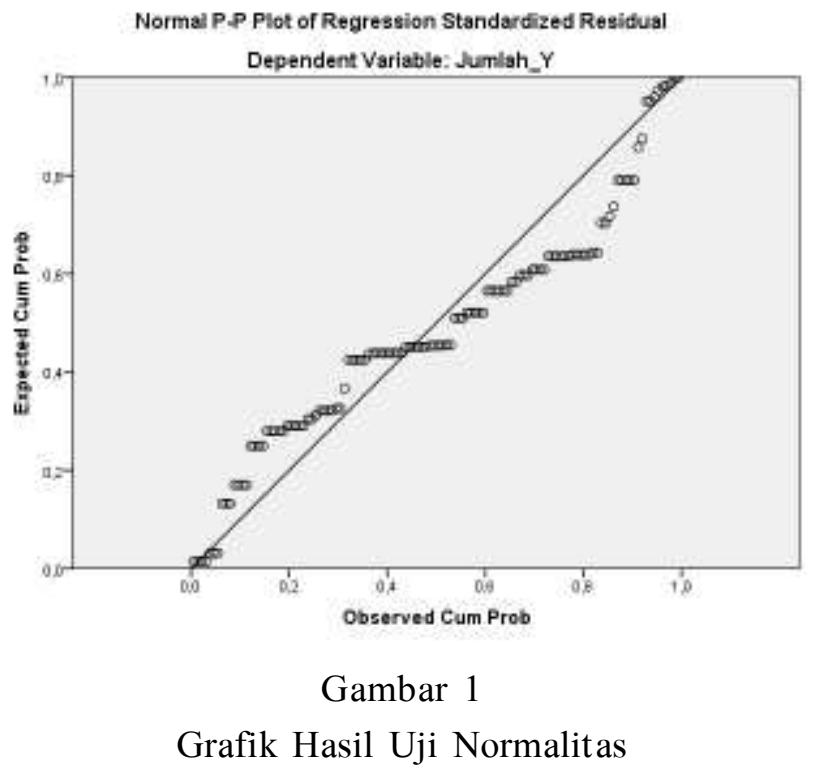

Sumber: Data primer yang diolah 2015

Berdasarkan grafik di atas menunjukkan bahwa plot/ titik-titik menyebar dan mengikuti arah garis diagonal, berada disekitar dan disepanjang garis 45 derajat, jadi dapat disimpulkan asumsi normalitas terpenuhi, sehingga model regresi layak dipakai karena memenuhi asumsi normalitas.

\section{Uji Linearitas}

Uji linearitas digunakan untuk menguji apakah spesifikasi model yang digunakan sudah tepat atau lebih baik dalam spesifikasi model bentuk lain (Bawono, 2006:179). Uji linearitas dapat menggunakan metode langrange multiplier, yaitu bertujuan untuk mendapatkan nilai $\chi^{2}$, untuk mendapatkan $\chi^{2}$ dengan cara mengalikan jumlah data observasi dikalikan dengan $\mathrm{R}^{2}$ atau $\mathrm{n}^{*} \mathrm{R}^{2}$. Kriteria analisisnya adalah jika $\chi^{2}$ hitung $>\chi^{2}$ tabel, maka spesifikasi model persamaan regresi linear tidak benar, sedangkan $\chi^{2}$ hitung $<$ dari $\chi^{2}$ tabel, maka spesifikasi model persamaan regresi linear benar. Hasil output viewer dapat dilihat dibawah ini: 
Tabel 6

Hasil Uji Linearitas

\begin{tabular}{|l|l|r|r|c|}
\hline Model & $\mathrm{R}$ & R Square & $\begin{array}{c}\text { Adjusted R } \\
\text { Square }\end{array}$ & $\begin{array}{c}\text { Std. Error of the } \\
\text { Estimate }\end{array}$ \\
\hline 1 &, $092^{\mathrm{a}}$ &, 009 &,- 017 & 3,61119776 \\
\hline
\end{tabular}

a. Predictors: (Constant), x3_2, x1_2, x2_2

b. Dependent Variable: Unstandardized Residual

Sumber: Data primer yang diolah 2015

Untuk mencari $\chi^{2}$ hitung, dengan cara mengalikan $\mathrm{n} * \mathrm{R}^{2}=120 *$ $0,009=1,08$. Sedangkan untuk $\chi^{2}$ tabel diketahui : 146,5670 dengan tingkat signifikan $5 \%$ dan df $=116$. Karena $\chi^{2}$ hitung ${ }^{-}$dari $\chi^{2}$ tabel, maka spesifikasi model persamaan regresi linear benar, sehingga dapat disimpulkan bahwa model yang benar adalah model linear.

\section{Uji Hipotesis}

\section{Analisis regresi berganda}

Analisis regresi berganda digunakan untuk mengetahui seberapa besar pengaruh rotasi kerja (X1), motivasi kerja (X2), kepuasan kerja (X3) terhadap kinerja karyawan BMT Taruna Sejahtera Ungaran (Y). Persamaan regresi linear berganda dicari dengan rumus:

$$
\mathrm{Y}=\beta_{0}+\beta_{1} \mathrm{X}_{1}+\beta_{2} \mathrm{X}_{2}+\beta_{3} \mathrm{X}_{3}+e
$$

Tabel 7

Hasil Uji Analisis Regresi Berganda

Coefficients $^{\mathrm{a}}$

\begin{tabular}{|c|c|c|c|c|c|}
\hline \multirow[t]{2}{*}{ Model } & \multicolumn{2}{|c|}{$\begin{array}{l}\text { Unstandardized } \\
\text { Coefficients }\end{array}$} & \multirow{2}{*}{$\begin{array}{c}\begin{array}{c}\text { Standardized } \\
\text { Coefficients }\end{array} \\
\text { Beta }\end{array}$} & \multirow[b]{2}{*}{$\mathrm{T}$} & \multirow[b]{2}{*}{ Sig. } \\
\hline & B & Std. Error & & & \\
\hline 1 (Constant) & $-12,335$ & 3,462 & & $-3,563$ & ,001 \\
\hline Jumlah_x1 & ,364 & ,079 & ,299 & 4,582 & ,000 \\
\hline Jumlah_X2 & ,296 & ,070 & ,372 & 4,219 &, 000 \\
\hline Jumlah_X3 & ,235 &, 063 & ,310 & 3,741 & , 000 \\
\hline
\end{tabular}

a. Dependent Variable: Jumlah_Y

Sumber: Data primer yang diolah 2015 
Berdasarkan output SPSS di atas, maka diperoleh persamaan regresi sebagai berikut:

$$
Y=-12,335+0,364 X_{1}+0,296 X_{2}+0,235 X_{3}+0,05
$$

Dari persamaan tersebut dapat diambil kesimpulan bahwa:

1) Konstanta sebesar $-12,335$ menyatakan bahwa jika ada rotasi kerja (X1), motivasi kerja (X2) dan kepuasan kerja (X3) konstan atau tidak ada atau 0, maka kinerja karyawan akan mengalami penurunan sebesar 12,335 .

2) Koefisien regresi rotasi kerja (X1) sebesar 0,364 menyatakan bahwa setiap penambahan 1 point rotasi kerja (X1) akan meningkatkan kinerja karyawan sebesar 0,364 dengan anggapan motivasi kerja (X2) dan kepuasan kerja (X3) tetap.

3) Koefisien regresi motivasi kerja (X2) sebesar 0,296 menyatakan bahwa setiap penambahan 1 point motivasi kerja (X2) akan meningkatkan kinerja karyawan sebesar 0,296 dengan anggapan rotasi kerja (X1) dan kepuasan kerja (X3) tetap.

4) Koefisien regresi kepuasan kerja (X3) sebesar 0,235 menyatakan bahwa setiap penambahan 1 point kepuasan kerja (X3) akan meningkatkan kinerja karyawan sebesar 0,235 dengan anggapan rotasi kerja (X1) dan motivasi kerja (X2) tetap.

\section{Uji $t_{\text {tes }}$ (uji secara individu atau parsial)}

Uji ini digunakan untuk melihat tingkat signifikansi variabel independen mempengaruhi variabel dependen secara individu atau sendirisendiri. Pengujian ini dilakukan secara persial atau individu, dengan menggunakan uji $t$ statistik untuk masing-masing variabel bebas, dengan tingkat kepercayaan tertentu (Bawono, 2006: 89). Hasil uji $t_{\text {test }}$ dapat dilihat dibawah ini: 
Tabel 8

Hasil Uji $\mathrm{t}_{\text {test }}$

\section{Coefficients $^{\mathrm{a}}$}

\begin{tabular}{|c|c|c|c|c|c|}
\hline \multirow[t]{2}{*}{ Model } & \multicolumn{2}{|c|}{$\begin{array}{c}\text { Unstandardized } \\
\text { Coefficients }\end{array}$} & $\begin{array}{l}\text { Standardized } \\
\text { Coefficients }\end{array}$ & & \\
\hline & B & Std. Error & Beta & $\mathrm{T}$ & Sig. \\
\hline 1 (Constant) & $-12,335$ & 3,462 & & $-3,563$ & ,001 \\
\hline Jumlah_x1 & ,364 & 079 & 299 & 4,582 & ,000 \\
\hline Jumlah_X2 & ,296 & ,070 & ,372 & 4,219 &, 000 \\
\hline Jumlah_X3 & ,235 & ,063 & ,310 & 3,741 & ,000 \\
\hline
\end{tabular}

Berdasarkan hasil uji t, peneliti mendapatkan nilai t hitung masingmasing untuk rotasi kerja (X1), motivasi kerja (X2) dan kepuasan kerja (X3) menunjukkan bahwa variabel rotasi kerja (X1) dengan t hitung 4,582 dan nilai signifikansi jumlah rotasi kerja (X1) 0,000, dimana nilai signifikansi lebih kecil dari nilai alfa 0,05 maka dapat dikatakan bahwa rotasi kerja (X1) secara statistik berpengaruh dan signifikan terhadap kinerja karyawan (Y). Dengan demikian secara empiris menolak Ho dan menerima H1, yang menyatakan bahwa rotasi kerja berpengaruh positif dan signifikan terhadap kinerja karyawan (Y). Hal ini berarti semakin tinggi tingkat rotasi kerja yang dilakukan maka semakin tinggi juga kinerja karyawan tersebut.

Hasil penelitian ini konsisten dengan pernyataan Kaymaz (2010) bahwa rotasi kerja dapat memberikan kepuasan kerja dan meningkatkan produktifitas kerja yang tinggi, rotasi kerja merupakan metode yang efektif untuk mengembangkan keterampilan dan meningkatkan kepuasan kerja yang pada akhirnya berpengaruh terhadap kinerja. Hasil penelitian ini mendukung penelitian sebelumnya yang dilakukan oleh Nurlatifah (2009), Putri (2013) dan Andriani (2013) yang menyatakan bahwa rotasi kerja berpengaruh positif dan signifikan terhadap kinerja karyawan. Artinya ketika rotasi kerja meningkat maka kinerja karyawan juga akan mengalami peningkatan. Namun, hasil penelitian ini tidak mendukung penelitian Anggraini (2013) yang menunjukkan hasil yang berbeda yaitu rotasi kerja berpengaruh negatif terhadap kinerja karyawan. Artinya ketika rotasi kerja meningkat, maka kinerja karyawan mengalami penurunan.

Variabel motivasi kerja (X2) dengan t hitung 4,219 dan nilai signifikansi jumlah motivasi kerja (X2) 0,000, dimana nilai signifikansi lebih kecil 
dari nilai alfa 0,05 maka dapat dikatakan bahwa motivasi kerja (X2) secara statistik berpengaruh dan signifikan terhadap kinerja karyawan (Y). Dengan demikian secara empiris menolak Ho dan menerima H2, yang menyatakan bahwa motivasi kerja berpengaruh positif dan signifikan terhadap kinerja karyawan (Y). Hal ini berarti semakin tinggi motivasi kerja maka semakin tinggi juga kinerja karyawan tersebut.

Hasil penelitian ini konsisten dengan pernyataan Buhler (2001) bahwa motivasi dapat meningkatkan kinerja karyawan dengan memenuhi (atau melampaui) tujuan-tujuan organisasi. Hasil penelitian ini mendukung penelitian sebelumnya yang dilakukan oleh Rahmawati (2010) dan Nitasari (2012). Namun, hasil penelitian ini tidak mendukung penelitian Murti dan Veronika (2013) yang menunjukkan hasil bahwa motivasi berpengaruh negatif terhadap kinerja karyawan. Artinya ketika motivasi kerja meningkat, maka kinerja karyawan mengalami penurunan.

Variabel kepuasan kerja (X3) dengan t hitung 3,741dan nilai signifikansi jumlah kepuasan kerja (X3) 0,000, dimana nilai signifikansi lebih kecil dari nilai alfa 0,05 maka dapat dikatakan bahwa kepuasan kerja (X2) secara statistik berpengaruh positif dan signifikan terhadap kinerja karyawan (Y). Dengan demikian secara empiris menolak Ho dan menerima H3, yang menyatakan bahwa kepuasan kerja berpengaruh positif dan signifikan terhadap kinerja karyawan (Y). Hal ini berarti semakin tinggi kepuasan kerja maka semakin tinggi juga kinerja karyawan tersebut.

Hasil penelitian ini konsisten dengan pernyataan Martoyo (1987) bahwa kepuasan kerja tercermin pada perasaan karyawan terhadap pekerjaannya, yang sering diwujudkan dalam sikap positif karyawan terhadap pekerjaannya dan segala sesuatu yang dihadapi ataupun ditugaskan kepadanya di lingkungan kerjanya, ketika kepuasan kerja itu meningkat maka kinerja karyawan tersebut juga meningkat. Hasil penelitian ini mendukung penelitian yang dilakukan oleh Syahbandar (2011) dan Wahab (2012). Hasil penelitian ini tidak mendukung penelitian yang dilakukan oleh Gumilar (2010) yang menunjukkan hasil yang berbeda bahwa kepuasan kerja berpengaruh negatif terhadap kinerja karyawan. Artinya ketika kepuasan kerja meningkat, maka kinerja karyawan mengalami penurunan. 


\section{Uji $F_{\text {test }}$ (Uji Secara Serempak)}

Uji F dilakukan dengan tujuan untuk mengetahui seberapa jauh semua variabel independen secara bersama-sama dapat mempengaruhi variabel dependen (Bawono, 2006:91).

Tabel 9

Hasil Uji $F_{\text {test }}$

ANOVA $^{\mathbf{b}}$
\begin{tabular}{|ll|r|r|r|r|r|}
\hline Model & \multicolumn{1}{|c|}{$\begin{array}{c}\text { Sum of } \\
\text { Squares }\end{array}$} & \multicolumn{1}{c|}{ Df } & $\begin{array}{c}\text { Mean } \\
\text { Square }\end{array}$ & \multicolumn{1}{c|}{ F } & Sig. \\
\hline 1 & Regression & 11523,031 & 3 & 3841,010 & 292,021 &, $000^{\mathrm{a}}$ \\
& Residual & 1525,769 & 116 & 13,153 & & \\
& Total & 13048,800 & 119 & & & \\
\hline
\end{tabular}

a. Predictors: (Constant), Jumlah_X3, Jumlah_x1, Jumlah_X2

b. Dependent Variable: Jumlah_Y

Sumber: Data primer yang diolah 2015

Pada tabel di atas menunjukkan bahwa F hitung 292,021 dengan nilai signifikasi 0.000 . Karena probabilitas signifikan jauh lebih kecil dari 0.05 maka Ho ditolak dan Ha diterima. Hal ini menunjukkan bahwa H4 yang diajukan dapat diterima yang menyatakan bahwa rotasi kerja, motivasi kerja dan kepuasan kerja secara bersama-sama berpengaruh terhadap kinerja karyawan.

\section{Uji $\mathbf{R}^{2}$ (Koefisien Determinasi)}

Menurut Bawono (2006:92) koefisien determinasi $\left(\mathrm{R}^{2}\right)$ menunjukkan sejauh mana tingkat hubungan antara variabel dependen dengan variabel independen atau sejauh mana kontribusi variabel independen mempengaruhi variabel dependen. 
Tabel 10

Hasil Uji R ${ }^{2}$

\section{Model Summary}

\begin{tabular}{|l|r|r|r|r|}
\hline Model & $\mathrm{R}$ & R Square & $\begin{array}{c}\text { Adjusted R } \\
\text { Square }\end{array}$ & $\begin{array}{c}\text { Std. Error of } \\
\text { the Estimate }\end{array}$ \\
\hline 1 &, $940^{\mathrm{a}}$ &, 883 &, 880 & 3,62673 \\
\hline
\end{tabular}

a. Predictors: (Constant), Jumlah_X3, Jumlah_x1,

Jumlah_X2

Sumber: Data primer yang diolah 2015

Dari tabel di atas terlihat koefisien korelasi (R) sebesar 0.940 ini artinya ada hubungan sebesar 0.940 antara variabel dependen (kinerja karyawan) dengan variabel independen (rotasi kerja, motivasi kerja dan kepuasan kerja). Sehingga dapat disimpulkan korelasi antara rotasi kerja, motivasi kerja dan kepuasan kerja terhadap kinerja karyawan mempunyai hubungan yang kuat. Koefisien determinasi (Adjusted R) sebesar 0,880 ini berarti kontribusi variabel independen (rotasi kerja, motivasi kerja dan kepuasan kerja) mempengaruhi variabel dependen (kinerja karyawan) sebesar 88\% sedangkan sisanya sebesar $12 \%$ dipengaruhi variabel lain di luar model.

\section{Penutup}

Berdasarkan dari hasil penelitian ini maka dapat ditarik kesimpulan bahwa terdapat pengaruh positif dan signifikan rotasi kerja (X1), motivasi kerja (X2) dan kepuasan kerja (X3) terhadap kinerja karyawan (Y) BMT Taruna Sejahtera. Hal ini menunjukkan bahwa semakin tinggi rotasi kerja, motivasi kerja dan kepuasan kerja maka kinerja karyawan akan meningkat. Hasil penelitian ini juga menunjukkan bahwa rotasi kerja (X1), motivasi kerja (X2) dan kepuasan kerja (X3) secara bersama-sama berpengaruh positif dan signifikan terhadap kinerja karyawan (Y). Saran untuk peneliti selanjutnya terkait kinerja karyawan perlu melihat faktor-faktor lain misalnya etos kerja, lingkungan kerja, kepemimpinan dan stres kerja, serta melibatkan lebih banyak responden dalam melakukan penelitian yang dapat mempengaruhi kinerja karyawan. 


\section{Daftar pustaka}

Armstrong, Michael. 1988. Manajemen Sumberdaya Manusia. Jakarta: PT Elex Media Komputindo.

Bawono, Anton. 2006. Multivariate Analysis dengan SPSS. Salatiga : STAIN Salatiga Press.

Andriani, Novi. 2013. "Persepsi Kesesuaian Kompensasi dan Rotasi Pekerjaan Terhadap Kinerja Karyawan PT. Kereta Api Indonesia (Persero) Daerah Operasi IX Jember”. Skripsi. Jember: Fakultas Ekonomi (Jurusan Akuntansi) Universitas Jember.

Anggraini, Normala Dewi. 2013. "Pengaruh Praktek Knowledge Management Terhadap Kinerja Organisasi (Studi Empiris Pada Satuan Kerja Perangkat Daerah Kota Salatiga)". Skripsi. Fakultas Ekonomika Dan Bisnis Universitas Diponegoro Semarang.

Buhler, Patricia. 2011. Alpa Teach Yourself Management Skills dalam 24 Jam. Jakarta: Prenada Media.

Davis, Keith dan John W. Newstrom. 1985. Human Behavior at Work: Organizational Behavior. Jakarta: Erlangga.

Ghozali, Imam. 2001. Aplikasi Analisis Multivariate Dengan Program S.PSS. Semarang: Badan Penerbit Universitas Diponegoro.

Gomes, Faustino Cardoso. 2003. Manajemen Sumber Daya Manusia. Yogyakarta: ANDI.

Gumilar, Eko Agung. 2010. "Pengaruh Faktor-Faktor Kepuasan Kerja Terhadap Kinerja Karyawan PT.X”. Universitas Islam Negeri Syarif Hidayatullah. Jakarta.

Mangkunegara, Anwar Prabu. 2004. Manajemen Sumber Daya Manusia Perusahaan. Cetakan pertama Bandung: PT Remaja Rosdakarya.

Mangkunegara, Anwar Prabu. 2008. Manajemen Sumber Daya Manusia Perusahaan. Bandung: PT Remaja Rosdakarya.

Indrayati, Monic Aprilia. 2014. "Analisis Pengaruh Rotasi Pekerjaan dan Motivasi Kerja Terhadap Kinerja Karyawan Melalui Kepuasan Kerja Pt. Bank Tabungan Negara (Persero) Tbk. Kantor Cabang Semarang". Skripsi. Semarang: Fakultas Ekonomi dan Bisinis Universitas Diponegoro Semarang.

Kaymaz, Kurtulus. 2010. "The Effects of Job Rotation Practices on Motivation: A Research on Managers in the Automotive Organizations. Business and Economics Research" Journal Vol.1, No.3 2010.

Martono, Nanang. 2010. Metode Penelitian Kuantitatif-Analisis Isi dan Analisis Data Sekunder. Jakarta: Raja Grafindo Persada. 
Martoyo, Susilo 1987. Manajemen Sumber Daya Manusia. Yogyakarta: BPFE. Mulyani, Sri. 2007. "Analisis Perilaku Konsumen Terhadap Produk Tabungan Perbankan Syariah (Studi Kasus Pada BRI Syari ah Cabang Solo)". Skripsi. Surakarta: Jurusan Ekonomi Islam Sekolah Tinggi Agama Islam Negeri Surakarta.

Murti, Harry dan Veronika Agustini Sri Mulyani. 2013. "Pengaruh Motivasi Terhadap Kinerja Pegawai Dengan Variabel Pemediasi Kepuasaan Kerja Pada Pdam Kota Madiun”. Program Studi Manajemen, Universitas Katolik Widya Mandala Madiun Vol. 1 No. 1, Februari 2013.

Nitasari, Rizka Afrisalia. 2012. "Analisis Pengaruh Motivasi Kerja Terhadap Kinerja Karyawan Dengan Kepuasan Kerja Sebagai Variabel Intervening Pada PT. Bank Central Asia Tbk. Cabang Kudus". Skripsi. Semarang: Fakultas Ekonomi dan Bisnis Universitas Diponegoro Semarang.

Nurlatifah. 2009. "Pengaruh Rotasi Kerja Terhadap Kinerja Pustakawan di Perpustakaan Universitas Gadjah Mada Yogyakarta”. Skripsi. Yogyakarta: Fakultas Adab (Program Studi Ilmu Perpustakaan Jurusan Ilmu Perpustakaan dan Informasi) Universitas Islam Negeri Sunan Kalijaga Yogyakarta.

Putri, Putu Ayu Cintya Permata.2013. "Analisis Pengaruh Rotasi Pekerjaan Dan Pengembangan Karir Terhadap Motivasi Dan Kinerja Karyawan Pada Pt.Bank Jatim Cabang Jember”. Universitas Jember. Jember.

Rahmawati, Ita. 2010. "Pengaruh Pelatihan Dan Motivasi Karyawan Terhadap Kinerja Karyawan Bagian Produksi Pt. Lotus Indah Textile Industries Surabaya". Skripsi. Fakultas Ekonomi Universitas Pembangunan Nasional "Veteran" Jawa Timur.

Rivai, Veithzal dan Ella Jauvani Sagala. 2009. Manajemen Sumber Daya Manusia Untuk Perusahaan: Dari Teori ke Praktik. Jakarta: Rajawali Pers.

Robbins, Stephen P. dan Timothy A. Judge. 2008. Perilaku Organisasi. Jakarta: Salemba Empat.

Santoso, Budi dan Agung Riyardi. 2012. "Rotasi, Mutasi Dan Promosi Karyawan Di Kantor Pelayanan Pajak Pratama Klaten". Program Pasca Sarjana Magister Manajemen Universitas Muhammadiyah Surakarta, Jurnal Ekonomi Manajemen Sumber Daya Vol.13, No.1, Juni 2012.

Siagian, Sopar Sihar Imanuel. 2015. "Pengaruh Pelatihan, Kepuasan Kompensasi, Motivasi Dan Disiplin Kerja Terhadap Kinerja Karyawan" jurnal ilmu dan riset manajmen vol. 4 no. 9 ,agustus 2015. 
Syahbandar. 2011. "Analisis Kepuasan Kerja Karyawan pada PT Sandi Pratama-Batam”. Skripsi. Pekanbaru: Fakultas Ekonomi (Jurusan Manajemen) Universitas Islam Riau Pekanbaru.

Wahjono, Sentot Imam. 2010. Perilaku Organisasi.Yogyakarta: Graha Ilmu.

Wahab, Rahmatullah Burhanuddin. 2012. "Pengaruh Kepuasan Kerja dan Motivasi Kerja Terhadap Kinerja Karyawan Pada PT. Bank Mandiri (Persero) Tbk. Makassar". Skripsi. Makassar: Fakultas Ekonomi dan Bisnis Universitas Hasanuddin Makassar.

Wibowo. 2010. Manajemen Kinerja. Jakarta: Rajawali Pers.

Wijaya, Tony. 2013. Metodelogi Penelitian Ekonomi dan Bisnis Teori dan Praktik. Yogyakarta: Graha Ilmu. 